\title{
SOMATIC THEORIES OF MIND AND THE INTERESTS OF MEDICINE IN BRITAIN, $1850-1879$
}

by

\section{S. JACYNA*}

\section{INTRODUCTION}

BOTH the content and the social context of nineteenth-century British psychiatric thought have received considerable historiographic attention in the past decade. From these studies a number of broad features have emerged. On the one hand, two apparently contradictory approaches to the understanding and treatment of madness were current during this period. While "moral" theories of insanity regarded derangement as an affliction of the mind and proposed to treat it by kindness and appeals to the sufferer's intellect and feelings, a contrary physicalist aetiology located the causes of madness in a disorder of the body, and insisted that it could only be treated by somatic remedies. ${ }^{1}$ This typology is, of course, over-simple. It ignores the many different combinations of moral and physical theories that appeared in the course of the nineteenth century. During the 1830 s, for example, a physicalist account of the causes of mental disease co-existed quite amicably with a primarily moral therapeutics. ${ }^{2}$ By the end of the century, however, a more complete polarization seems to have taken place, and British psychiatric orthodoxy adhered to both somaticist aetiology and treatment, to the rigid exclusion of other more psychological approaches. ${ }^{3}$

On the other hand, historians have described the way in which the nineteenth century saw the emergence of a definite professional group whose business was madness. During the eighteenth century the traffic in lunacy "was a trade monopolised by no single group". It was only late in the century that the medical profession began to claim a special competence in this area and to attempt to exclude other groups from a share of this growing empire. During the $1800 \mathrm{~s}$,

mad-doctors manoeuvred to secure such a position for themselves and acceptance of their particular view of the nature of madness, seeking to transform their existing foothold in the marketplace into a cognitive and practical monopoly of the field, and to acquire for those practising this line of work the status

*L. S. Jacyna, Ph.D., Wellcome Institute for the History of Medicine, 183 Euston Road, London NW1 2BP.

${ }^{1}$ See William F. Bynum, 'Rationales for therapy in British psychiatry: 1780-1835', Med. Hist., 1974, 18: 317-333; Andrew T. Scull, 'Moral treatment reconsidered: some sociological comments on an episode in the history of British psychiatry', Psychol. Med., 1979, 9: 1-8.

${ }^{2}$ Roger J. Cooter, 'Phrenology and British alienists, c. 1825-1845', Med. Hist., 1976, 20: 1-21, 135-151.

${ }^{3}$ Michael Clark, 'The rejection of psychological approaches to mental disorder in late nineteenth-century British psychiatry', in Andrew Scull (editor), Madhouses, mad-doctors, and madmen: the social history of psychiatry in the Victorian era, London, Athlone Press, 1981, pp. 271-312. 


\section{S. Jacyna}

and prerogatives 'owed' to professionals - most notably autonomous control by the practitioners themselves over the conditions and conduct of their work.4

By the end of the nineteenth century, the mad-doctors, or alienists, had largely secured these aims - but not without difficulty. Their efforts at aggrandizement had to meet and overcome other interested groups who also claimed to have some say in the management of the insane. ${ }^{4 a}$

A crucial point that has become clear from the works cited above is that these two processes - the intellectual and the social - were not independent. On the contrary, they were so intimately connected that it is impossible to understand either without a knowledge of the other. As Dr. Bynum has shown, the promulgation of moral therapeutic theories at the turn of the nineteenth century had an immediate impact upon the efforts of medical men to consolidate and increase their grip on the asylums. Those hostile to these ambitions found in the theories of Pinel and Esquirol, and still more in the practice of Samuel Tuke at the York Retreat, a means of challenging medical pretensions. While Pinel had questioned the value of the physical therapies conventionally applied in the treatment of the insane, Tuke had demonstrated the possibility of a regime in which "the physician was a shadowy figure, the burden of therapeutic responsibility having fallen on the Keepers and other staff." These widelypublicized developments had ominous implications for the advocates of medical control of the insane: "If physicians qua physicians could do nothing for the lunatic except treat his bodily affliction, then the medical man had no special claim to a unique place in the treatment of mental illness. Their income, prestige, and medical theories were all threatened."s

Alienists were quick to reply to this threat. The form of their response tended to be a restatement of the validity of somaticism sustained by some appeal to "scientific" and "objective" facts. ${ }^{6}$ It is in this light, Dr. Cooter has argued, that British alienists' receptivity to the claims of phrenology should be viewed. Given the danger posed by moral treatment to the position of physicians in asylums, what medical men needed was "a means of legitimating the humanitarianism and utilitarianism of the moral treatment while simultaneously justifying their place in asylums as the purveyors of essential medical expertise." Phrenology met this need because it "elevated the moral treatment to a scientific status ... it brought the mind and psychology via the brain fully into the province of somatic medicine just as it had brought the brain in psychiatry into the domain of biology."'

The history of nineteenth-century British psychiatry therefore offers an especially promising field for the investigation of the influence of material interests upon the development and use of a body of knowledge. The aim of this paper is to build upon and supplement the existing studies in order to demonstrate further this interdependence. Professor Scull has argued that the polemical concerns of the early

\footnotetext{
4Andrew T. Scull, Museums of madness: the social organization of insanity in nineteenth-century England, London, Allen Lane, 1979, p. 129.

"I Ibid., pp. 126-130.

3 Bynum, op. cit., note 1 above, pp. 323-325.

Ibid., p. 328.

' Cooter, op. cit., note 2 above, pp. 135-136, 141.
} 


\section{Somatic theories of mind and the interests of medicine}

nineteenth century continued to preoccupy alienists in its middle decades. The issue of who was to supervise the insane remained very much alive. Moreover, in supporting their claims, alienists still turned to physicalism: indeed, they became less ready to admit the value of "moral" remedies and more and more intent on asserting the sole value of physical treatment as part of their efforts to secure their professional prerogatives. $^{8}$

However, Professor Scull does not give an adequate account of the content of midVictorian psychiatric ideas. The following section examines the different strata of physicalist theory at this time, and asks how overtly new elements were related to established modes of thought. The concluding section seeks to locate these changes, as well as the continuities, in concepts of insanity in their polemical context. More generally, it enquires how far the interests articulated by physicalism in the latter half of the nineteenth century can be seen as extensions of those of an earlier period, and to what extent they expressed novel concerns and emphases.

\section{CHANGE AND CONTINUITY IN MID-VICTORIAN PSYCHIATRIC THEORY}

British neuroscience underwent great changes in the decade 1840-50. In the first place, reflexion was gradually recognized as the general mode of nervous function. Second, the ganglion was admitted as the anatomical substrate of the reflex. Both of these concepts had been familiar to earlier neurology; however, their application had been much narrower than it became during this period. Reflexion, as conceived by Marshall Hall in the 1830s, applied only to certain actions mediated by the spinal cord. These were entirely separate from the majority of nervous operations which were dependent upon the determination of the will and executed by another mechanism.' The ganglion was originally regarded as a predominantly peripheral structure, found chiefly in the "vegetative" nervous system. The existence of some ganglia at the posterior roots of the spinal nerves was, nonetheless, conceded..$^{10}$

During the 1840s, the reference of both these terms was expanded. "Reflexion" was considerably elaborated, and held to characterize the working of the hind- and midbrains, and finally of the cerebral hemispheres themselves. " Similarly, the definition of the ganglion was revised to give it a wider compass. Instead of regarding external form as the most important characteristic, British neurologists increasingly relied upon histological texture to distinguish ganglionic structures. The existence of "vesicular neurine", or nerve cells, was presented as sufficient evidence that a given tissue was a ganglion. By this standard, the central nervous system could be portrayed as a chain of semi-autonomous ganglia.

This model of nervous structure and function coexisted with a variety of

Scull, op. cit., note 4 above, pp. 130-132, 141-143, 155-159, 164-165.

' Marshall Hall, Memoirs of the nervous system, London, Sherwood, Gilbert \& Piper, 1837, pp. 49-50, 70; idem, Synopsis of the diastaltic nervous system, London, Joseph Mallet, 1850, p. vii.

10 Charles Bell, The nervous system of the human body, 3rd ed., Edinburgh, Adam \& Charles Black, 1836, pp. 8-9.

"William B. Carpenter, A manual of physiology, including physiological anatomy for the use of the medical student, London, John Churchill, 1846, pp. 490-491, 504; idem, Principles of human physiology with their chief applications to pathology, hygiene, and forensic medicine, 4th ed., London, John Churchill, 1853, pp. x-xii, 672. 


\section{S. Jacyna}

psychological positions. It was possible to deny that its tenets in any way challenged the dualist doctrine that mind and body were separate entities; or that the control that the former exercised over the latter was called into question. While, in some instances, bodily actions did appear to have purely "material" causes - that is, they were responses to mechanical stimuli mediated by the nerves and ganglia - in others, it was held, the soul manipulated the mechanism of reflexion to suit its purposes. ${ }^{12}$ Those who took this view were careful to insist that, although there clearly was some intimacy between the form and operation of the nervous system and the phenomena of "mind", "we are not, therefore, authorized to conclude that mental action results from the physical working of the brain."13

On the other hand, this was precisely the conclusion which others wished to draw from physiology and anatomy. Thomas Laycock was among the most articulate of these. ${ }^{14} \mathrm{He}$ wrote in 1860 that he had begun his enquiries thirty years before with the express aim of achieving the "union of philosophy proper with physiology". Specifically, Laycock tried to establish the doctrine that "every change in the consciousness is coincident with some vital change in the encephalon .... Without such vital change, no mental phenomena whatever are manifested."15

Such "physiological psychology" must have wide implications. As early as 1844 , Laycock told the Medical Section of the British Association for the Advancement of Science that, since it had been "generally acknowledged that the brain is the organ of mind, the study of its physiology or laws of action, has acquired a surpassing interest, for whatever men do, in the most comprehensive sense, is connected with its functions." However, Laycock went on to indicate those specialist concerns to which physiological psychology was most relevant: it was "as elucidating the nature and treatment of insanity, that [the brain's] physiology is most interesting to physicians."16 As well as its general significance, Laycock suggested that the kind of neurology that he had helped to establish was especially germane to the activities of physicians wholly or mainly engaged in the treatment of insanity. As he told a meeting of alienists in 1862, the project of a physiological psychology was "one of the highest importance to their professional success; it is to determine how far a mental science in the true meaning of the term science is possible, and capable of practical application to mental pathology, therapeutics and hygiene, and the needs of society in general."17

By the time Laycock made these remarks, there was plentiful evidence that he was

\footnotetext{
12 See, for example, Robert B. Todd and William Bowman, The physiological anatomy and physiology of man, 2 vols., London, John W. Parker, 1845, vol. 1, p. 234.

13 Ibid., p. 262.

14 Thomas Laycock (1812-76) was lecturer on clinical medicine at York medical school until 1855 when he became Professor of the Practice of Medicine at Edinburgh University. On Laycock, see Roger Smith, 'Physiological psychology and the philosophy of nature in mid-nineteenth-century Britain'. Cambridge PhD thesis, 1970, pp. 71-97.

15 Thomas Laycock, Mind and brain: or the correlations of consciousness with organisation; with their applications to philosophy, zoology, physiology, mental pathology, and the practice of medicine, 2 vols., Edinburgh, Sutherland \& Knox, 1860, vol. 1, p. 45.

16 Thomas Laycock, On the reflex function of the brain, London, C. \& J. Adlard, [n.d.], p. 1.

17 Thomas Laycock, On the principles and method of a practical science of mind. A reply to criticism, London, J. E. Abelard, 1862, p. 3.
} 


\section{Somatic theories of mind and the interests of medicine}

preaching to the converted. In the course of the 1850s, leading members of the British psychiatric profession had set out with the avowed aim of discovering the import of advances in neurology to their branch of medical science. This section describes the content of the mental pathology they produced, and, in particular, the relation of these doctrines to new concepts in the physiological anatomy of the nervous system.

It is misleading to speak, as contemporaries sometimes did, of the "implications" of developments in neuroscience for mental pathology. There was no unproblematic inference from the one to the other: implications had to be constructed rather than merely extrapolated. The physiological anatomy of the previous decades did not determine the form of the mental pathology of the 1850s and 1860s; instead it provided a mass of material which, together with other resources, was shaped to meet particular ends.

A distinctive feature of the physiological psychology of the mid-nineteenth century was its dynamic element. In contrast to earlier efforts (such as those of phrenology) to correlate the mental and the organic, it sought the connexions between the two spheres in time as well as in space. The concept of reflexion provided the framework for an analysis which linked sensation and adaptive response to a succession of physical circumstances which had certain consequences. The union between mental and organic was therefore conceived as an event, not merely as a site. ${ }^{18}$

The theoretical and experimental elaboration of this notion of a temporal and dynamic relation between mind and nervous system provided a potential for scientific practice that was extensively exploited during the later nineteenth century, especially in Germany. ${ }^{19}$ The concept was also open to application in pathology. If sound sensation and movement depended upon the reflexive mechanism, then morbid symptoms would be considered as the result of diseased innervation of the higher sensory and motor ganglia. ${ }^{20}$

There is some evidence that British writers on mental pathology in the midnineteenth century recognized the possibility of an account of mental disorder along these lines. Indeed, Laycock had come to questions of the nature of insanity through a study of convulsive diseases such as epilepsy. He saw an analogy between these and the "emotional" convulsions of hysteria. It was to explain this analogy that Laycock argued for an extension of the reflex model of nervous action from the spine to the encephalon. ${ }^{21}$

The actions mediated by the latter differed from the former only in that they were

\footnotetext{
18 See Alexander Bain, Mind and body. The theories of their relation, 2nd ed., London, Henry S. King, 1873, pp. 36-37; G. Canguilhem, 'Le concept de réflexe au XIXe siècle', in K. E. Rothschuh (editor), Von Boerhaave bis Berger: die Entwicklung der kontinentalen Physiologie im 18. und 19. Jahrhundert mit besonderer Berücksichtigung der Neurophysiologie, Stuttgart, G. Fischer, 1964, pp. 157-167.

19 See Herbert A. Langfield, 'The historical development of response psychology', Science, 1933, 77: 243-50; Franklin Fearing, Reflex action: a study in the history of physiological psychology, New York and London, Hafner, 1964, pp. 232-253.

${ }^{20}$ Wilhelm Griesinger, 'Ueber psychische Reflexactionen. Mit einem Blick auf das Wesen der psychischen Krankheiten', in C. Wunderlich (editor), Gesammelte Abhandlungen. Erster Band. Psychiatrische und Nervenpathaligische Abhandlungen, 2 vols., Berlin, August Hirschwald, 1872, vol. 1, pp. 3-45; idem, 'Neue Beiträge zur Physiologie und Pathologie des Gehirns', ibid., pp. 46-79.

${ }^{21}$ Thomas Laycock, $A$ treatise on the nervous diseases of women: comprising an inquiry into the nature, causes, and treatment of spinal and hysterical disorders, London, Longmans, 1840, pp. 85-86.
} 


\section{S. Jacyna}

accompanied by consciousness. Both classes of movement were motor reactions to sensory stimuli. When this process was impaired, then these responses deteriorated into convulsive spasms. When the cerebral ganglion was thus affected, the consequences of morbid innervation extended to the psyche: the emotions and the reason also became subject to convulsive fits. In Laycock's words,

the cranial ganglia, although the organ of consciousness, are subject to the same laws [i.e., of reflexion] as those which govern the other ganglia, .... In short ... the passions and the movements dependent on them, as laughing, sighing, sobbing; the instinctive feelings and their conjoined movements; and the whole series of spasmodic and convulsive movements, from those of epilepsy and chorea down to the retraction of the foot of a decapitated frog, are seated in the same grand division of the nervous system, and depend on the same general laws. ${ }^{22}$

In 1844, Beverley Morris advanced a similar form of analogical reasoning as a means of understanding all kinds of insanity. Given the "similarity in the structure and functions of the brain and spinal cord", it was reasonable to infer that the two might be subject to comparable defects. However, because of the additional role of the brain as the organ of mind, abnormal stimulation of its substance would have "two sets of effects ... one manifested by some impairment of its mental faculties, and the other by the induction of some distant disease." When the spinal cord was subject to irritation,

we find its ordinary functions are disordered - i.e., the nervous functions of the supplied part are deranged - usually manifested in reduced power. In like manner, I believe that, when irritation exists in the brain, its ordinary - i.e. its mental, functions are disordered, manifested by deranged perception, or the loss of some other faculty denoting that its power is impaired. I would not, however, confine its effects to the mental faculties, but would extend them to the influence which it manifestly exerts over many of the corporeal functions. ${ }^{23}$

Morris held that such cerebral irritation might have a variety of causes. "Idiopathic" causes acted "through the mind". In contrast, "reflexive" causes acted through the corporeal functions. Later writers of this school tended to emphasize the latter source of irritation at the expense of the former.

Thus Henry Monro distinguished three theories as to the sources of "mental obliquity". There was, first, the notion that insanity was caused by the "spiritual agency of an evil nature". Second, the body could be conceived as playing a "secondary part ... where it is made instrumental to evil spiritual agency". Finally, the causes of insanity could be identified as "wholly and primarily of bodily origin". The brain, "the mental instrument", functioned imperfectly and deranged the operations of the mind. Monro announced his own conviction that "insanity is essentially dependent on this last source of mental obliquity". ${ }^{24}$

Like Laycock, Monro presented the concept of reflexion as a means of comprehending the nature of this obliquity. In its healthy state the nervous mechanism that is, the brain as well as the spinal cord - enjoyed a balance between afferent and efferent stimuli; this equilibrium Monro called "nerve tone". If this tone was distur-

22 Ibid., p. 107.

${ }^{23}$ Beverley R. Morris, A theory as to the proximate causes of insanity together with some observations upon the remote causes of the disease, London, Henry Renshaw, 1844, pp. 6-7.

${ }^{24}$ Henry Monro, Remarks on insanity: its nature and treatment, London, John Churchill, 1851, pp. iii-iv. 


\section{Somatic theories of mind and the interests of medicine}

bed, by a deficit or an excess in either half of the reflexive cycle, pathological states followed. In the case of the spine, excessive motor responses led to spasms; deficient sensitivity to a paralysis of motion. Similarly,

When the cerebral masses are suffering from this condition of depressed vitality, they lose that static equilibrium of the nervous energies which we call tone (and which is peculiarly indicative of healthy vigour) and they exhibit in their functions the two different degrees of nervous action ..., namely, irritable excess of action, and partial paralysis; . . . in consequence, the brain becomes an imperfect instrument for the manifestation of mind; and . . . its operations are distorted either into irritable and diseased excess, or more or less suspended altogether. ${ }^{2 s}$

But it was Henry Maudsley ${ }^{26}$ who provided the most elaborate statement of how the principles of reflexion could illuminate sound and morbid mental activity. To understand the working of the higher nervous centres, he argued, it was necessary to comprehend the simpler type of neural structure and function evident in the spinal cord. Such knowledge was "an indispensable pre-requisite to the right understanding of the higher displays of nervous function, and alone fixes the sure basis whereon to build a true mental science." Maudsley cited with approval Wilhelm Griesinger's efforts to extend these insights from normal to pathological psychology. ${ }^{27}$

Two elements can be distinguished in the kind of mental pathology current among British alienists in the mid-nineteenth century. In the first place, there is an insistence on the somatic origins of mental disorder to the virtual exclusion of "spiritual" causes. In addition was the more specific claim that the way in which these physical causes impinged on the mind was best comprehended on a reflex model of nervous function. Of the two, the first was extensively developed in the medical psychology of the period. Indeed, the physical causation of insanity often appeared to be the central contention of this literature.

The second proposition received less attention. British authors seemed more interested in the use of reflex theory in reinforcing their existing biases than in elaborating its explanatory potentials. Thus, after an account of how in health the brain exercised an "inhibitory power over the nervous centres below it", Maudsley expatiated upon the pathogenic consequences of a relaxation of this control which allowed the lower reflexive centres to operate unchecked. He concluded:

Such, then, are the disturbing causes which may affect the activity of the spinal cord both as a conducting path and as an independent centre of the generation of nerve-power. When we reflect upon the great proportion of the daily actions of life that are effected by its unconscious agency, we cannot but perceive how most important is the due preservation of its integrity. No culture of the mind, however careful, no effort of the will, however strong, will avail to prevent irregular and convulsive action when a certain degree of instability of nervous element has, from one cause or another, been produced in the spinal cells. It would be equally absurd to preach control to the spasms of chorea, or restraint to the convulsions of epilepsy, as to preach moderation to the east wind, or gentleness to the hurricane. That which in such case has its foundation in a definite physical cause must have its cure in the production of a definite physical change. ${ }^{28}$

$2 s$ Ibid., pp. 12-13.

${ }^{26}$ Henry Maudsley (1835-1918) was medical superintendent at the Manchester Royal Lunatic Hospital, 1859-62; editor of the Journal of Mental Science, 1864-70; and Professor of Medical Jurisprudence at London University, 1869-79. He was extensively involved in schemes to promote psychological research in Britain.

${ }^{27}$ Henry Maudsley, The physiology and pathology of the mind, London, Macmillan, 1867, pp. 83-84.

23 Ibid., p. 83. 


\section{S. Jacyna}

In this way, reflexology served to reinforce psychiatric physicalism and to discredit any notion of the "moral" causation and treatment of insanity.

Moreover, the notions of mental disturbance sometimes presented as inferences from modern reflex theory were often no more than a refurbished version of conventional ideas of madness which bore no real debt to any physiological doctrine. The view that sound nervous function depended on the inhibition of the lower nervous centres by the brain was little more than a "scientific' statement of the theory current for most of the nineteenth century that insanity involved an abrogation of the normal regulation of the impulses by the will. This opinion was firmly rooted, not only in medical literature, but in the general assumptions of Victorian middle-class culture. ${ }^{29}$

There was also a discrepancy between what alienists promised to derive from reflex theory and what they in fact delivered. While their physiology of mind might contain features drawn from the latest trends in neuroscience, their mental pathology continued to rely on traditional classifications and models. This was true even of Maudsley, the most sophisticated of British writers on the subject during this period. His section on "Reflex Irritation" as a cause of insanity was really concerned with sympathetic causes; that is, with how an affection of one organ could impair the condition of the brain. ${ }^{30}$ As such, Maudsley's mental pathology referred, not to contemporary neurophysiology, but to the concern of eighteenth- and early nineteenthcentury medicine with the way in which localized disease could have more general consequences. ${ }^{31}$ Just how traditional this kind of mental pathology was can be seen by a comparison between Maudsley's writings and those of W. A. F. Browne on the dependence of the brain on the well-being of other organs, which were published thirty years earlier. ${ }^{32}$

In short, British alienists showed only a limited awareness of, or interest in, the possibilities of reflex theory to give a novel account of the physical bases of mental disorder ${ }^{33}$ They tended to neglect the potential in contemporary physiological psychology for a dynamic account of the inter-relations of mind and body. There was, however, a somewhat greater interest shown in the more static aspects of neurology, and especially in the search for the organic lesions which gave rise to mental disturbance.

Throughout the first half of the nineteenth century in Britain, alienists had tried to find in the brains of the insane the structural causes of their illness. ${ }^{34}$ Members of the phrenological school were particularly energetic in these attempts. ${ }^{35}$ Comparable

\footnotetext{
${ }^{29}$ See Vieda Skultans, Madness and morals: ideas of insanity in the nineteenth century, London and Boston, Routledge \& Kegan Paul, 1975, pp. 13-17.

${ }^{30}$ Maudsley, op. cit., note 27 above, pp. 236-245.

${ }^{31}$ For a discussion of the doctrine of sympathy, see Ruth Leys, 'Background to the reflex controversy: William Alison and the doctrine of sympathy before Hall', Stud. Hist. Biol., 1980, 4: 1-66, Part I.

32 W. A. F. Browne, What asylums were, are, and ought to be, Edinburgh, Adam \& Charles Black, 1837, pp. 6-7.

${ }^{33}$ The most important British writer on the pathological applications of reflex theory, John Hughlings Jackson, was unconnected with the asylums system.

${ }^{34}$ See John Haslam, Observations on madness and melancholy: including remarks on those diseases; together with cases: and an account of the morbid appearances on dissection, London, J. Callow, 1809, pp. 87-184.

${ }^{3 s}$ Cooter, op. cit., note 2 above, p. 144.
} 


\section{Somatic theories of mind and the interests of medicine}

investigations took place in the 1850s and later. One of the most extensive of these exercises occurred in 1853, when James Davey published the results of a survey of the brains of 100 mad persons. Of these, he maintained, only eight were without structural defect; all the others showed morbid signs in the grey matter, medullary substance, ventricles, or membranes. ${ }^{36}$

Davey conceived cerebral function as analogous to that of a gland. The hemispheres secreted "nervous power" much as the liver secreted bile, through a series of chemical and physical changes in the grey and medullary substances. He went on to assert that it followed that "any causes calculated to interfere with such ... changes, whether it operate either by increasing or decreasing their frequency, or altering their order of succession, must, if it exceed certain limits, lead to the secretion of a 'nervous power' of so altered a quality or quantity, as to induce disease, insanity." 37

Davey speculated that of the varieties of cerebral substance, the grey matter was most important to mental activity. Its derangement was consequently the most likely source of insanity. He concluded that in the "grey matter of the brain, then, is located the proximate cause of insanity". In particular, the inflammation of the cineritious neurine had serious effects on the mind. ${ }^{38}$

The main features of Davey's account were replicated in the literature of the next decade. His stress upon the connexion between the substance of the hemispheres and normal cerebral performance was retained; the analogy between the cerebrum and a gland developed; the grey matter was acknowledged to be the active component in the "secretion" of thought. Further, inflammation of this neurine was admitted as an especially important source of mental disease.

However, this continuity in pathological thinking was, to some extent, obscured by a number of novel elements which were grafted, usually with little skill, on to this scheme. The new theories of the nervous system, and trends in physiological anatomy generally, contributed the means of restating old doctrines in a novel idiom. In particular, they supplied materials for elaborating the anatomical basis of the mind that supposedly lay in the brain. A central resource in this endeavour was the concept of the ganglion defined as an essentially cellular structure.

Just as the sound function of the brain had been referred to a histological foundation in the 1840s, so were cerebral dysfunctions explained in terms of deformity in the tissues of the hemispheres during the subsequent decade. The authors of the major textbook of medical psychology in mid-Victorian Britain made it a leading principle of their science that pathological and physiological principles should be intertwined in this way: a "rational pathology" was "an account of the abnormalities of organization and function, which as much depend on the nature of the laws of life as our health".

\footnotetext{
${ }^{36}$ James G. Davey, On the nature, and proximate causes of insanity, London, John Churchill, 1853, p. 58. Davey was medical superintendent and proprietor of the Northwood Asylum near Bristol from 1855; and resident physician at Middlesex Lunatic Asylum from 1865.

37 Ibid., p. 24.

36 Ibid., pp. 28, 43.
} 


\section{S. Jacyna}

While sanity relied upon "the repose of the brain", cerebral pathology must assume that "mental diseases result from the interruption or disruption" of the conditions of healthy function of the grey matter of the cortex. ${ }^{39}$

Attention was focused upon the "vesicular neurine" in these investigations. The brain cells were the source of the nervous force of the brain; moreover, they were "the agents of all that is called mind ... ; and the growth and renovation of these cells is the most ultimate condition of mind with which we are acquainted." 40 This notion of the cell as the seat of vital action was in keeping with the general trend of the previous decade to identify the ultimate units of function at the microscopic level. In particular, by the early 1850 s the cell was widely recognized in British physiology texts to be the ultimate secreting structure. ${ }^{41}$

By a free use of the power of "analogy", British medical psychologists of the midnineteenth century perpetuated the earlier image of the cerebral hemispheres as a gland that secreted nervous power and thought. But, in keeping with the wider tendency, they came to identify the active element in this process, not with the grey matter en masse, but with the constituent cells of the neurine. Joshua Burgess provided an example of this mode of reasoning in 1858 . He wrote that the "functions of consciousness, perception and ideas; the acts of memory, will, and understanding" were secreted by the cerebral gland. Specifically, the source of mental power "is in the 'vesicular neurine' of the grey ganglia."42

In taking the cell as the seat of pathogenic change, theorists of insanity were also merely following a much wider tendency in contemporary medical science. This was towards the abandonment of the distinction between "functional" and "organic" diseases, and to the recognition that all diseases followed from structural deformities. Adam Addison reported in 1863 that the "study of pathological anatomy had entirely changed the character of medical science, which, instead of a chaotic medley of unfounded theories and ingenious hypotheses, ... is now resting on a firm foundation of facts with mutual and definite relations." It was only in exceptional cases that it was impossible to "demonstrate certain gross, palpable changes of structure having an invariable causal connection with functional disturbances." Above all, the period after 1858 had seen the promulgation in Germany of Virchow's cellular pathology, which "has given us an insight into the arcana of cell-life, and laid down the comprehensive generalisation as the basis of a new pathology, that the cell is the ultimate agent by which, both in health and disease, structural and functional alterations are effected." ${ }^{43}$

${ }^{39}$ John C. Bucknill and Daniel H. Tuke, $A$ manual of psychological medicine: containing the history, nosology, description, statistics, diagnosis, pathology, and treatment of insanity, 2nd ed., London, John Churchill, 1862, pp. 383-384.

40 Ibid., p. 385.

41 See my 'Scientific naturalism in Victorian Britain', Edinburgh PhD thesis, 1980, chap. 3 section ii.

42 Joshua Burgess, The medical and legal relations of madness; showing a cellular theory of mind, and of nerve force, and also of vegetative and vital force, London, John Churchill, 1858, pp. 13-14. Burgess was medical superintendent and proprietor of Wigston Lunatic Asylum, Leicester.

${ }^{43}$ Adam Addison, 'On the pathological anatomy of the brain in insanity', J. ment. Sci., 1863, 8: 37-61 (37). On Virchow's cellular pathology, see W. H. McMenemy, 'Cellular pathology, with special reference to the influence of Virchow's teachings on medical thought and practice', in F. N. L. Poynter (editor), Medicine and science in the 1860s, London, Wellcome Institute, 1968, pp. 13-43. 


\section{Somatic theories of mind and the interests of medicine}

Bucknill and Tuke claimed that Virchow himself had sanctioned a cellular theory of the basis of mental function and therefore of mental disease. The brain, like any other organ, they argued, required for its operations "the perfect condition of its organization". Consequently, "the existence of any pathological state in the organ of the mind interrupts the functions of that organ, and produces a greater or less amount of disease of the mind - that is, insanity".44

However, despite this stress upon cellular deformation as the cause of disease, in their proposed aetiology of insanity Bucknill and Tuke paid most attention to the relations of the cell. The "ultimate condition of the mind" was the proper "nutrition" of the brain cell, but this was performed by non-cellular structures: namely, the nerves, which transmitted impulses to and from the neuron, and the fine capillary network which permeated the vesicular neurine and fed the cells with blood. Bucknill and Tuke held that: "All states, either physiological or pathological, of the cerebral cell, are occasioned by influences impressed upon it, either by the nerves or the blood vessels, with which it stands in such intimate relation .... The cause of change must be sought for in the nerve or the capillary."4s

Of the two, the nerve could only impair the cell by an excessive stimulus. On the other hand, capillary disorder could lead to a wide variety of dysfunctions in the growth and renovation of the vesicular neurine. Bucknill and Tuke gave much greater weight, on these grounds, to circulatory, rather than neural failures as a cause of mental disease.

They could cite Virchow's authority for this bias. He too had maintained that cells operated in the context of "anatomical units", comprising vascular and nervous networks. Moreover, he had also conceived these to be "fundamentally vascular units, $\ldots$ in consequence of his unwillingness to allow nerve fibres any trophic or nutritive influence over cells." 46

But Bucknill and Tuke's concentration upon capillary action had foundations which predated the concepts of cellular pathology. As noted above, insanity had earlier in the nineteenth century been identified as a result of cerebral inflammation. During this period great attention was paid to the part played by the blood in inflammatory disorders generally: in particular, an irregular passage of the blood through the capillaries was seen as crucial to an understanding of such diseases. ${ }^{47}$

Bucknill and Tuke, op. cit., note 39 above, pp. 385-387.

is Ibid., p. 386.

${ }^{46}$ L. J. Rather, Addison and the white corpuscles: an aspect of nineteenth-century biology, London, Wellcome Institute, 1972, p. 131.

${ }^{47}$ Ibid., pp. 50-51. See also, Samuel Solly, The human brain, its configuration, structure, development, and physiology; illustrated by reference to the nervous system in the lower orders of animals, London, Longman, 1836, pp. 365-367; George Burrows, On disorders of the circulation; and on the connection between affections of the brain and diseases of the heart, London, Longman, 1846. The links between disease of the cerebral circulation and mental disorder were major themes in French pathological anatomy of the 1820s and 1830s: see, for example, Achille Louis Foville, 'Encéphale', in Dictionnaire de médicin et de chirurgie pratiques, 15 vols., Paris, Mequignon-Marvis, J.-B. Baillière, 1829-36, vol. 7, pp. 191-250 (especially pp. 223-229); J. Bouillaud, 'Encéphalité', ibid., pp. 250-279 (especially pp. 262-269); F. Lallemand, Recherches anatomico-pathologiques sur l'encéphale et ses dépendances, 3 vols., Paris, Chez Béchet, 1830, vol. 2, pp. 77-80, 330-333, 467-470, vol. 3, pp. 92-93, 178-183; M. J. Bouillaud, Traité clinique et physiologique de l'encéphale, ou inflammation du cerveau, et des suites, Paris, J. B. Baillière, 1825. 


\section{S. Jacyna}

Bucknill and Tuke were typical of their style of mental pathology in retaining this inflammatory model of mental illness, while drawing freely on the newer cellular pathology. The latter was not integral to their notion of the causation of mental disease; rather it was a thin veneer of modernity spread over what was essentially a vascular theory of the conditions of cerebral function.

Thus Bucknill and Tuke admitted that the state of the capillary vessels of the vesicular neurine was as close as pathology could come to the anatomical bases of insanity. The pathological changes of the cells themselves were inscrutable; nonetheless, they confidently asserted that "in most instances of insanity arising from physical causes, it is probable that the pathological condition of the cerebral cells is subsequent to, if not dependent upon, the pathological condition of the cerebral capillaries." Such capillary defects could be induced by injury to the head, fever, "suppressed discharges", and alcohol.48

Burgess similarly held that, even if the analogy between the brain and the glands could not be fully sustained, there could be no question that the former was as dependent as the latter on a healthy blood supply. Disruption of this supply led to "phrenitis" - i.e., cerebral inflammation - which, Burgess alleged, was "a type to exemplify particularly the diseases of madness". ${ }^{49}$

There was, therefore, a discrepancy between the pretensions and the reality of British mental pathology in the mid-nineteenth century. It claimed to derive its principles from the latest advances in neuroscience. But, in fact, its use of the explanatory potentials of reflex action was casual. Moreover, although greater interest was shown in the histological aspects of contemporary neurology, the concepts of cellular anatomy and pathology were attached loosely to a pre-existing system which held insanity to be usually derived from inflammation of the hemispheres, and which traced this fault to a capillary defect. Continuity, rather than innovation, was the most salient feature of somatic theories of madness current in the mid-nineteenth century. ${ }^{30}$

The following section suggests that a critical attitude is also needed in assessing the claims that were made about the uses of such doctrines. It argues that the continuity between the 1850 s and 1860 s and the early nineteenth century was not only a conceptual one. Certain features of the social context of the psychiatric profession remained stable over this period, imposing interests upon alienists to which somatic pathologies of mind were instrumental. Although there were some novel elements in the way these doctrines were employed in the later period, these were changes of emphasis not of basic orientation.

For a discussion of French psychiatric physicalism, see Erwin H. Ackerknecht, Medicine at the Paris Hospital 1794-1848, Baltimore, Md., Johns Hopkins Press, 1967, pp. 167-172. The influence of these authors on British medical psychology would reward study.

48 Bucknill and Tuke, op. cit., note 39 above, pp. 415, 418.

4 Burgess, op. cit., note 42 above, pp. 51-52, 65-66. See also, Forbes Winslow, On obscure diseases of the brain, and disorders of the mind: their incipient symptoms, pathology, diagnosis, treatment, and prophylaxis, London, John Churchill, 1860, pp. 14, 634-635.

so In fact, the alienists were old-fashioned even in their notion of inflammation as a capillary disorder. By the $1860 \mathrm{~s}$, it was usual for greater stress to be placed upon the surrounding tissue in the explanation of the disease: Rather, op. cit., note 46 above, p. 83. 


\section{Somatic theories of mind and the interests of medicine}

\section{THE INTERESTS OF MEDICINE}

Alienists and their supporters insisted upon the "practical" importance of a physicalist conception of insanity. Laycock claimed that physiological psychology was helping to establish an "applied science of man", which was especially relevant to "an elucidation of the nature and treatment of insanity". He maintained that: "The enlightened physician has long been convinced, that a science of Life and Organisation, built on the solid foundations of a sound mental philosophy, is an essential requisite to the proper development of a science of medicine; without that, the practice of medicine can never be anything more than an art."'s1

In a letter to George Combe, Laycock revealed that his labours in medical psychology had been undertaken "solely with a view to their practical applications". In an "eclectic spirit" he had utilized "all available sources of Knowledge . . . on the one hand mental philosophy proper so far as it has truths fit for use; on the other hand, phrenology, physiognomy, cerebral physiology and biology so far as they afford truths fit for use."'s2

In 1862, Laycock tried to convince the meeting of the Association of Medical Officers of Asylums that if its members were "to build up a true mental science, available to the pressing needs of society, and especially to the right development of mental pathology, therapeutics, and hygiene", they could not scorn the theoretical exercises in which he and others were engaged..$^{3}$

In fact, such exhortations were hardly necessary. Throughout the nineteenth century, alienists had shown a keen appreciation that questions of mental pathology, and even the most abstract doctrines of the relation of mind to body, impinged upon their professional interests. Such concerns were evident in their main organ the Journal of Mental Science. The aim of this section is to consider which interests were served by the particular account of the causes of insanity articulated by the spokesmen of the alienists in the works discussed above.

The many references in the literature to the need for a "scientific" medicine - one which would provide a true knowledge of the aetiology of disease and so the means of effective therapy - might suggest that an interest in obtaining instrumentally-powerful knowledge was paramount. Certainly, Bucknill and Tuke declared it to be a major end of therapy to "remove the pathological condition of the brain" which neuroscience showed to be the cause of insanity. However, the therapeutic techniques they proceeded to enumerate showed little connexion with the pathological theories they had expounded. One practical recommendation that could be linked to their cerebral pathology was to use bleeding to relieve the hyperaemia of the hemispheres resulting from blocked blood vessels. In addition, because congestion in the head was supposed to depend upon general congestion of bodily systems, purgatives were prescribed to remedy both conditions. Further, rubbing "counter-irritants" into the scalp would, it was alleged, draw to the surface whatever was inflaming the cortex and thus heal

\footnotetext{
s1 Laycock, op. cit., note 15 above, vol. 1, pp. v-viii. (43).

32 Laycock to Combe, 17 September 1857, Combe Papers, National Library of Scotland, 7365 ff $43-44$

${ }^{33}$ Laycock, op. cit., note 17 above, p. 23.
} 


\section{S. Jacyna}

disordered mental functions. ${ }^{34}$

But even these "remedies" were long-established parts of the armoury of the alienist: they had been employed on the insane for over a century independently of the elaborate histological pathology with which they were coupled in the 1850s and 1860s. Bleeding had been one of the panaceas of eighteenth-century medicine and was lavishly used in the asylums. Purgation was as venerable; the chief difference between its use in the mid-eighteenth and in the mid-nineteenth centuries lay in the substances administered..$^{35}$ Bucknill and Tuke were embarrassed at the crudity of these methods, but they obviously had little else to offer the practising alienist.

The other treatments they mentioned were as traditional and had still less to do with their pathology. In fact, the main object of most of their therapy was to keep the patient quiet rather than to effect a cure. Opium, cold showers, warm baths, and wet blankets were all recommended for this purpose. The likely debilitating effect of continual bleeding and purging can also be accommodated to the view that the aim of alienists was to make their patients more amenable to control and that the current mental pathology had little if any impact on their clinical practice. Although Henry Maudsley in 1867 declared that a "truly scientific treatment will be grounded upon the removal of those bodily conditions which appear to have acted as causes of [mental] disease", the treatments he suggested fell into the same pattern of suppressing symptoms rather than remedying causes. ${ }^{36}$

This analysis confirms the suggestion that most "treatment" in the asylums was really an effort to discipline inmates. The medical terminology of therapy adorned what were essentially managerial techniques. ${ }^{37}$ It also suggests that the actual interests which somatic theories of madness served in the mid-nineteenth century need to be sought elsewhere.

One function which they evidently performed in the life of the psychiatric profession was to supply a token of group membership and to serve as an expression of solidarity among alienists. On two occasions, W. A. F. Browne, Superintendent of the Crichton Institute at Dunbar and a prominent member of the Asylum Officers' Association, wrote to request George Combe's assistance in securing the appointment of a particular candidate on the grounds that "He holds correct views on the nature of Insanity," and "It appears to me that a man of practical experience in the management of the Insane in seclusion - and holding correct views on the nature of Insanity should be appointed". ${ }^{38}$ The views referred to were those which regarded insanity as "a disease of the afferent parts of the tissues of which the mental phenomena are .. . the symptoms".s9

Such talk of "correct" views is reminiscent of the idiom of political parties

s4 Bucknill and Tuke, op. cit., note 39 above, pp. 507-510.

ss Cf. Richard Hunter and Ida Macalpine, Three hundred years of psychiatry 1535-1860: a history presented in selected English texts, London, Oxford University Press, 1963, pp. 234, 344, 370-372.

${ }^{56}$ Maudsley, op. cit., note 27 above, pp. 435-440.

"s? Scull, op. cit., note 4 above, pp. 202-203.

se Browne to Combe, 22 May 1849 and 14 August 1857, Combe Papers, op. cit., note 52 above, 7299 ff $39-40(40)$ and 7538 ff $117-119$ (118-119). Italics added.

39 Browne to Combe, 18 April 1857, ibid., 7312 ff 148-149 (149). 


\section{Somatic theories of mind and the interests of medicine}

organized round an explicit ideology. The function of doctrine in such groups is twofold: it helps to secure the internal cohesion of the party and to define it vis-à-vis other sects. Browne confirmed this notion of an essentially political role for physicalist theories of madness when he held that deviation from these views "cannot be regarded in any better light than as a treason to the principles of our profession". ${ }^{60}$

On this view, the interests which somatic mental pathology expressed are to be found in the institutional location of the alienists and in their relations with other social groups. Of special relevance are the continuities of the mid-Victorian period and the earlier nineteenth century.

By 1845, the medical profession had achieved considerable success in its efforts to obtain control over the public asylum system. They had gained a monopoly of the superintendencies of the asylums and guaranteed places for medical men on the Commission appointed to inspect the working of the madhouses. ${ }^{61}$ But efforts to consolidate and enhance these prerogatives continued to be obstructed by a variety of other interested groups who demanded a say in the government of asylums. The committees of Justices who oversaw these institutions, for example, did not hesitate to prefer their own judgment to that of medical officers on such questions as the release or detention of individuals - questions which the alienist insisted were of a clinical nature and his alone to decide. In some cases, the committees also attempted to intervene in the daily running of the asylum and to oblige the Superintendent to conform to their ideas of adequate treatment and provision for the insane. ${ }^{62}$ More generally, alienists complained that their role in the asylum was undervalued: a fact which was reflected not only in lack of public esteem, but also in the low remuneration they received for their efforts. ${ }^{63}$

Just as in the early nineteenth century the conflict between the proponents and enemies of medical control had possessed an ideological dimension, so in the later period too alienists felt themselves threatened by the currency of doctrines of the "moral" nature of insanity. J. T. Arlidge complained that, because of the exposure of the public to such ideas, the interests of the alienist had been damaged. This was due to the fact that "the moral means of treatment ... can, to a greater or less extent, be carried out equally by an unprofessional as a professional man. It is therefore not so surprising that the importance of a medical attendant is little appreciated, and that the value of medical treatment little heeded."

Arlidge was especially critical of those physicians who had joined the trend towards "moral" theories; he blamed these for

the oblivion into which medical aid has been allowed to fall, magistrates, like other mortals, have had their convictions strengthened, that medical superintendents, considered in their professional capacity, are rather ornamental than essential members of an asylum staff; very well in their way in cases of casual sickness or injury, useful to legalize the exit of inmates from the world, and not bad scape-goats

$\omega$ William A. F. Browne, 'The moral treatment of the insane', J. ment. Sci., 1864, 10: 309-337 (311).

61 Scull, op. cit., note 4 above, pp. 125-129.

62 Ibid., pp. 172-174.

$63 \mathrm{~J}$. T. Arlidge, On the state of lunacy and the legal provision for the insane, with observations on the construction and organization of asylums, London, John Churchill, 1859, pp. 101-103, 113. Arlidge (1822-99) was resident medical officer at St. Luke's Hospital from 1850. 


\section{S. Jacyna}

in misadventure and unpleasant investigations into the management, and in general not worse administrators, under the safeguard of their own magisterial oversight, than would be members of most other occupations and professions. 4

Moral concepts of insanity were, therefore, undermining the position alienists wished to secure for themselves in the asylums. ${ }^{65}$ In a similar vein, J. C. Bucknill had in 1857 censured John Conolly for maintaining that the "direct application of therapeutical means" was of dubious value in complaints of the "spirit". This was to concede the case of the alienists' enemies; the professionally proper emphasis, Bucknill argued, was upon the potential of recent neurophysiology to throw light on the physical correlates of mental disorder. ${ }^{66}$

The form of the strategy to which alienists resorted in the 1850s and 1860s was the same as that they had used in previous decades. However, as has been seen, the content was somewhat different. Although the same contentions were retained, these were now presented as inferences from the latest developments in neurology. This refurbishment of the materials used to make the same point can be referred to both a general and to a more specific polemical goal.

In the first place, phrenology was increasingly discredited as a serious physiological doctrine in the 1850s and even became the object of popular ridicule. ${ }^{67}$ This reduced its value as an underpinning for a somatic mental pathology: physicalist theories of insanity, and the interests they articulated, were in danger of becoming discredited along with the system that had supported them. W. A. F. Browne, himself a one-time phrenologist, informed his mentor George Combe in 1857 that if he were to state his views on the dependence of mental disorder on cerebral dysfunction in explicitly phrenological language, he would provoke incredulity. He had therefore attempted to preserve the spirit of phrenology - i.e., the basic tenet that mind relied on organization - while drawing upon more varied resources to sustain the claim. In particular, the "new" physiology of the nervous system had to be exploited for this purpose: "in giving a comprehensive sketch of the morbid phenomena of the Nervous System, in other words, of the whole range of Insanity, it is absolutely necessary to adopt a composite system including Bell's, Marshall Hall's ... etc. discoveries and opinions."

Physiological psychology was thus mobilized to fill a gap left by the decline in the respectability of phrenology: it was a partly novel way of continuing an old argument. This interpretation accounts for the slapdash fashion in which the new doctrines were incorporated into the mental pathology of the 1850s and 1860s. Alienists saw in

\footnotetext{
4 Ibid., pp. 103-104.

os See in this respect W. A. F. Browne's qualification of his earlier commitment to moral therapy on the grounds that, on such assumptions, "it will become the duty of the physician to give place to the divine or moralist": op. cit., note 60 above, p. 311 .

“ J. C. B[ucknill], "Review of "The treatment of the insane without mechanical restraints" by John Conolly', J. ment. Sci., 1857, 3: 253-261 (257-258). Bucknill (1817-97) was the first medical superintendent at the Devon Asylum from 1844 to 1862 , and medical visitor to lunatics from 1862 to 1876 . He founded the Journal of Mental Science and edited it from 1853 to 1862. See also, Bucknill and Tuke, op. cit., note 39 above, p. 498.

67 W. B. Carpenter's attack upon phrenology was seen as the beginning of the end for the scientific respectability of the creed: Carpenter, Principles, op. cit., note 11 above, 3rd ed., 1846, 751-757.

Growne to Combe, 30 April 1857, op. cit., note 52 above, 7312 ff 150-153 (151-152).
} 


\section{Somatic theories of mind and the interests of medicine}

physiological psychology the means of endowing their position with the appearance of modernity; they did not endeavour to make any basic revision of their doctrines in the light of its findings.

But, in some instances, the new theories served the polemical aims of the alienist better than the old. The attempts found in Bucknill and Tuke's textbook to attribute all mental disorders to "organic", or structural causes, can be related to the interest in vindicating the rights of the physician against the pretensions of the advocates of moral and spiritual theories of madness. "At bottom", Bucknill and Tuke conceded, the physiological and anatomical points they discussed resolved themselves "into the origin of thought and consciousness". The determination to locate this origin among the tissues of the cerebral hemispheres permeated the detail of their pathology. Bucknill and Tuke's emphasis upon the microscopic structure of the brain was an answer to those who used the absence of gross lesions in the brains of the insane as confirmation of the "prejudice" that led them to regard "insanity as the conditions of a certain metaphysical entity".69 Such resort to cellular, or sub-cellular, deformation as the physical root of madness became a standard ploy of later writers concerned to obviate the possibility of purely "moral" causes of derangement. ${ }^{70}$

The question of the dependence of sound mental function upon the supply of blood to the cerebrum also had this polemical significance. The issue was important because "it has been quite the custom among a certain class of writers to argue that the pathological changes discernible in the brains of insane persons are secondary changes of little importance to the elucidation of mental disease. Pinel, and after him, Esquirol, unfortunately expressed this view." "1

These quotations, which could be supplemented by others from different writers within this school of mental pathology, show somatic theories of mind serving the controversial goals of alienists. They were used to defend the rights of this group against the challenges which they faced. In this respect, there were strong resemblances between the social situation of the alienists in the 1850 s and 1860 s and in the earlier nineteenth century. The conceptual continuity between these periods noted above was matched by the persistence of comparable material interests.

However, by the mid-nineteenth century the alienists were no longer merely on the defensive. As well as safeguarding their existing position, they were seeking to expand their power and jurisdiction. The alienists took advantage of the fact that "insanity was such an amorphous, all-embracing concept, that the range of behaviour it could be stretched to encompass was almost infinite"; they argued that more and more forms of deviant behaviour could be regarded as "insane", or as analogous to insanity and therefore within their province. This cognitive aggrandizement had an institutional corollary: there was "an obvious link between how serious a problem insanity was perceived to be, and the importance and prestige bestowed upon those thought to be expert in its treatment. Naturally by increasing the population which fell

\footnotetext{
${ }^{69}$ Bucknill and Tuke, op. cit., note 39 above, pp. 415-418.

${ }^{70}$ Maudsley, op. cit., note 27 above, pp. 217-222.

"Bucknill and Tuke, op. cit., note 39 above, p. 418. See also, Davey, op. cit., note 36 above, pp. 1-6, 202-208, 43-49.
} 


\section{S. Jacyna}

within their purview, the profession also became entitled to obtain increased resources to support their activity."72

One important way in which alienists sought the related goals of enhanced status and augmented resources was to gain a greater say in the judicial process and so to redefine as insane some of those previously regarded as criminal. In so doing, however, the alienists impinged upon the territory of the legal profession: an intrusion which the lawyers resented and resisted. The alienists tended to assail the current legal definition of madness as an impairment of the "intellectual" faculties; on this view, a person was insane if he was unaware of the character of his actions. In place of this, they wished to institute a definition that emphasized the loss of volitional control in insanity which was brought about by bodily disorders. Behind this point of principle lay a question of professional competence. While a jury, when properly instructed by a judge, was capable of deciding unaided whether a person was aware of the moral character of his actions; alienists alleged that only a medically-qualified man could pronounce upon whether someone was clinically insane. ${ }^{73}$

Thus in an 1859 address to the annual meeting of the Medical Officers for Asylums, J. G. Davey criticized the criteria of lunacy embodied in the M'Naughton rules. He held that "the peers and judges who framed the law of lunacy as set forth in the preceding questions and answers, failed in their estimate of the indications of the disordered mind, its promptings to morbid movements, and to criminal acts, because they were no physiologists." An adequate law of lunacy had to be "in some harmony with the first principles of psychological medicine". It was the alienist's duty to introduce such legislation; however, the entrenched resistance of the legal profession could only be overcome by a sustained polemic:

if the peers and the judges of this realm are ever to be inclined to forego their own false views, and to substitute for them the only true psychology, the fact must be the result of much agitation, the consequence not of individual efforts, but of the resolutions and acts emanating from a society like unto this one. It will demand the authority of a Medical Association to assure the Legislature that insanity is to all intents and purposes, the very different affair to what it is made to appear in the questions and answers of the said judges. ${ }^{14}$

In the next year, Davey expatiated on this theme before the Association. He lamented the present state of the law which allowed lunatics, or potential lunatics, to go abroad until, "neglected and borne down by the pressure of disease of the brain, they were impelled - having lost their volition ... to the commission of crime." Such people should have long ago been "secluded and protected from the commission of crime". Moreover, when apprehended, "they were not subject to wholesome and necessary treatment, but they were treated as prisoners". Those who were not executed or transported "were made the companions of real criminals". All these evils had one cause: "these things had occurred only because insanity was not understood, because our Legislature did not care to make itself acquainted with the facts of insanity, and because they would not listen to the voice of those who did know what

\footnotetext{
7 Scull, op. cit., note 4 above, p. 238.

${ }^{73}$ The conflict between legal and medical views of madness is discussed in Roger Smith, Trial by medicine: insanity and responsibility in Victorian trials, Edinburgh University Press, 1981.

7 J. G. Davey, 'Relations between crime and insanity', J. ment. Sci., 1859, 5: 82-94 (86-88).
} 


\section{Somatic theories of mind and the interests of medicine}

insanity was. The lawyers would not be told by the doctors the true indications of cerebro-mental disease."'7s

In the discussion that followed Davey's address, the Asylum Officers' Association agreed to make approaches to Parliament and appointed a committee to press their case. In the face of legal opposition to the "medical" view of insanity, Davey declared, unless the alienists "agitated the question, they would never be heard". Another member maintained that "lawyers as a body were entirely deficient in knowledge in reference to the influence of physical organism upon mental acts". Further, "ignorance, gross and dark, pervaded the mind of the public upon these matters, and with regard to the results of physical disorder on mental acts." 76

Before "rational" legislation, which would give due weight to medical opinions, could be achieved, the public needed to be educated in the true nature of madness. Specifically, the doctrine that insanity was caused by a syndrome of the brain had to be placed upon an irrefragable basis. Thereby, the need for medical skills in its detection and its amenability to therapy would be established. This polemical interest was served by the somatic pathology of mind outlined above: this was the "scientific" foundation of the alienists' case.

The connexion between pathological doctrine and polemical interest was most blatant in Joshua Burgess' The legal and medical relations of madness. There the concept of the cerebrum as a mass of cells which "secreted nerve force and thought" was presented as grounds for the rejection of existing, legally-inspired concepts of insanity. Burgess complained that "the lawyers have the question [of whether a malefactor was insane] entirely in their own hands, and quite free and independent of medical interference, or of physiological testimony." This state of affairs was unjustifiable given the evident somatic bases of madness revealed by modern physiological anatomy: these showed insanity to be "an abnormal condition of the organic structure"."

The incompetence of lawyers to deal with such matters was manifest. Neither common sense nor jurisprudence could prevail in matters which required "medical advocacy". Burgess concluded that "lawyers may well blunder upon so uncongenial a subject as madness, and should hand it over to a physiological inquest." His contention was that, since "physiological and pathological conditions, are the best tests for madness", the determination of these "physiological investigations should form no part of the jurisprudence of the courts of law". ${ }^{78}$

A system of tribunals separate from the criminal courts should be established, Burgess maintained, to decide whether or not individuals were insane. These tribunals would examine minor offenders for signs of insanity and so protect society from their illness before they could commit further, more serious crimes. He stressed that the purpose of these courts would not be to punish but to take the insane entirely out of the ambit of the criminal law, and to ensure proper therapy for them. Under the

\footnotetext{
75 J. G. Davey, 'Insanity and crime', ibid., 1860, 6: 31-35 (31-32).

7 Ibid., pp. 35-37.

77 Burgess, op. cit., note 42 above, pp. vii, 2.

7 Ibid., pp. 4-6.
} 


\section{S. Jacyna}

auspices of the specialized tribunals, "curative institutions would grow up under magisterial supervision and authority, . . . and madness would come under medical treatment in that condition in which the practitioner, to his great disadvantage, never meets with it."'9

Society already countenanced the existence of a large number of similar probationary institutions: there could, therefore, be no objection in principle to the creation of such places of detention for the mentally-ill. Burgess argued that the existing county asylums were inadequate for this purpose. They should be confined for the use of incurables, while those whose insanity was capable of remedy should be housed in a new set of institutions. ${ }^{80}$

Burgess was unusually explicit in his demands for new tribunals, on which physicians would play a prominent part, to deal with cases currently heard by the ordinary criminal courts, and more asylums, to be run by alienists, where many of those now imprisoned would be kept. Nor did most other writers in the same tradition juxtapose such demands quite so obviously with their physicalist mental pathology. However, underlying much of this literature were calls for greater medical authority in the courts and for a diversion of offenders from punitive to "therapeutic" establishments. Further, somatic theories of mind were regularly deployed to legitimate these claims.

Thomas Laycock made his annual lectures on medical psychology at Edinburgh University instrumental to these ends. Although these were intended mainly for the instruction of physicians, Laycock saw lessons in his physiological psychology for members of other professions, especially lawyers. They would learn from his teaching that the "important question of civil and criminal responsibility turns . . . upon a diagnosis of the mental condition of the individual, founded upon physiological and pathological laws. The skilled physician is the proper person to be intrusted with this important duty." The law, as it stood, was incapable of dealing with a mass of mental deficients and lunatics who plagued society. But nothing would be easier than "the development and application of sound principles of mental science to the management of incorrigible vagabonds, thieves, and drunkards." 81

The lawyers, however, were impressed neither by the "scientific" character of the alienists' definition of madness nor by the prospect of a therapeutic policy towards the insane. They continued to defend their own criteria and authority. In 1862, the Lord Chancellor himself held that "the introduction of medical opinions and medical theories into the subject has proceeded upon the vicious principle of considering insanity as a disease; whereas the law regards it as a fact which can be ascertained by the evidence in like manner as any other fact." "Expert" opinion was unnecessary, he contended, to the legal definition of insanity. ${ }^{82}$

This declaration focused subsequent discussion. The alienists were outraged at such a rebuff of their attempts to enhance medical jurisdiction. D. H. Tuke in 1865

79 Ibid., pp. 161-163.

0 Ibid., pp. 226-227.

"1 Thomas Laycock, The scientific place and principles of medical psychology; an introductory address, Edinburgh, Murray \& Gibb, 1861, pp. 1-4.

:2 Parliamentary debates, 1862, 165: p. 1297. 


\section{Somatic theories of mind and the interests of medicine}

lamented the fact that the "lawyers so generally have their own way on this subject in public"; alienists rarely had the chance to reply. In particular, he condemned the "intolerable assurance which could induce the Lord Chancellor to assert that it is not necessary 'a man should have studied the subject of insanity in order to form a conclusion whether a man is or is not a lunatic'." Such arrogance "ought to arouse every alienist to maintain the dignity of his profession, and his primary right to form a judgment to which he has devoted his life". ${ }^{83}$

Laycock undertook to sustain the cause of medicine in this dispute in 1862 when he discussed the "distinct and complete ... antagonism between law and medicine" on questions of insanity. He also undertook to explain why the issue was of such "deep interest to the medical profession". Laycock condemned the Lord Chancellor's statements as designed to strengthen popular prejudices against medical definitions of insanity. However, Laycock also set these issues in context: he recognized that the triumph of either the "legal" or the "medical" concept of madness would bring with it important material consequences. While medicine "declares that insanity is a physical or corporeal disease; law declares that it is not ... . Medicine maintains that a theoretical and practical study of mental diseases and defects is necessary to the proper understanding and detection of mental disease or defect; law denies this." These contrasting definitions attached to different policies towards the "insane": "Medicine says, restrain and cure the insane and imbecile offender against the law; law says hang, imprison, whip, hunger him."

In other words, the legal and medical definitions of insanity led to different "careers" for the insane. In particular, the latter would channel greater numbers into medically-governed institutions and thus justify alienists' demands for enhanced resources.

In trying to establish this concept of madness, and all that it entailed, Laycock turned to "the somatic or corporeal doctrine of insanity". If the Lord Chancellor were acquainted with the tenets of contemporary neurophysiology, he would realize the vacuity of the legal position on insanity. These principles were "the proofs of the medical doctrine as to mental diseases and defects: they are facts which challenge every possible investigation and inquiry, and must be shown to be fallacious by those who take it upon themselves to deny the doctrine."

The conflict between lawyers and alienists formed part of a wider pattern. Many of the psychologists cited above regarded themselves as spokesmen not only for the alienists, but for medicine as a whole. They saw the slights and opposition they received from the lawyers as an aspect of the general undervaluing of the medical profession. Medicine was still a relatively parvenu profession, and suffered disadvantages in comparison with such established élites as the law. While the latter enjoyed high prestige and assured resources, medicine still bore the taint of being a mere "trade" and its practitioners were poorly remunerated. ${ }^{26}$

\footnotetext{
${ }^{83}$ Daniel H. T[uke], 'Review of "The legal doctrine of responsibility in relation to the insane" by $S$. W. North', J. ment. Sci., 1865, 11: 261-262(261).

Laycock, op. cit., note 17 above, p. 3.

os Ibid., pp. 5-6.

* See M. J. Peterson, The medical profession in mid-Victorian London, Berkeley, Los Angeles, and London, University of California Press, 1978, pp. 194-243.
} 


\section{S. Jacyna}

Thus in 1846, Laycock remarked that the "active existence of the [medical] profession in the body politic is but comparatively of recent date". It was necessary, he argued, for British society to adapt its political institutions to give this new estate its due voice. Moreover, the growing problems of sanitation and otherwise maintaining the health of an urban society demanded the existence of a "medical police" on the German model. The state should, therefore, undertake to employ large numbers of medical men to perform these functions. ${ }^{87}$

Similar complaints about the low status of medicine and demands for greater public employment of physicians recurred throughout the mid-nineteenth century. ${ }^{80}$ On occasion, alienists combined their own more particular polemical goals with a general attack upon the social position of medicine..$^{89}$ Burgess remarked that the "position of the medical profession is not well sustained; skill is more often treated as an impertinence than appreciated". Not only did the lawyers have their way on questions of insanity, but they, and the other old professions, tended to monopolize honours and patronage. However, Burgess warned, "problems of social improvement must be solved for which the astuteness of the lawyer, - the learning of the divine - and the labour of the statist, who have hitherto enjoyed state privileges and social position, may prove unavailing or obstructive; and the suggestion of the physiologist may be required to aid, or supersede them."90

Burgess pointed the form of a strategy which became increasingly prevalent during the 1860 s and 1870 s. In order to sustain their claims for enhanced status and resources, medical men descried a number of pressing "social problems" with which they alone were equipped to cope. They did this by attaching somatic causes to a wide range of deviant behaviour, which was thus identified as "pathological" and needing medical treatment. In this endeavour, the prior model of madness as disease of the nervous system was an important resource. Indeed, other "abnormalities" were presented as variations of the insane syndrome.

Laycock in 1860 stressed the affinities between the causes of insanity and other forms of "anti-social" behaviour. All, he suggested, should be subject to medical treatment. The kind of mental science at which he and others had arrived should form the basis of a social as well as an individual therapeutics. Its theories were necessary to happiness and success in life of the individual, "[and] must constitute the proper foundation of that social psychology which, under the name of sociology, politics, or political economy, applies a scientific knowledge of human nature to the wants of the many. In a nation, as in everything else, the whole is equal to the sum of all its parts; the collective whole reflects the individual elements. Practical sociology would therefore be the legitimate development of a practical mental science."91

"7 Thomas Laycock, The medical police of the United Kingdom, London, Reynell \& Wight, 1846, pp. 4-5, 13-15.

- See, for example, E. D. Mapother, The medical profession: and its educational and licensing bodies, Dublin, Finnin, 1868.

- Conversely, medical reformers sometimes took alienists' grievances and legal provisions for insanity as prime examples of their case: J. F. Clarke, The medical profession in its relations to society and the state, London, John Churchill, 1855, pp. 5-7.

5 Burgess, op. cit., note 42 above, pp. v-vii.

'L Laycock, op. cit., note 15 above, vol. 1, p. 22. 


\section{Somatic theories of mind and the interests of medicine}

In 1865, the Asylum Officers' Association changed its name to the MedicoPsychological Association. W. A. F. Browne, as President, announced that this change in title also signified a broadened scope for the practitioners of medical psychology: it indicated "a wider and more legitimate destiny for them." In particular, "we can no longer be mistaken for a mere friendly club or a mutual defence society. We may now claim as among our objects of investigation all subjects bearing upon the science of mind." Browne attached great importance to the role of mental psychology in preventing the spread of mental defects in the population; he described the "conservative mission of our science in anticipating, preventing and modifying mental maladies .... The laws of hérédité, moral and intellectual degeneration, and of intermarriage, constitute a science in themselves; and, perhaps, contain the basis of the future development and utility of prophylactic medicine."92

Browne indicated the main line which efforts to devise a "social pathology" would take in the subsequent decade. In the first place, an affinity between such apparently disparate behaviours as insanity, alcoholism, epilepsy, and crime was asserted. Next, these "moral" defects were assigned physiological roots; all were the effects of a diseased soma. Last, the hereditary character of these defects was outlined as a prelude to a suggested social policy to reduce their incidence. ${ }^{93}$

J. B. Thomson, Resident Surgeon at Perth Prison, set the pattern of this literature in 1870 . He alleged the existence of a "criminal class" in society. These criminals, who thronged the cities and "in hordes prey on society", also tended to have an inferior body-type. They were susceptible to insanity, dipsomania, and epilepsy; this, Thomson held, was proof that all these disorders had related causes. The physical degeneracy of this class gave rise to its "mental and moral depravity": their "moral disease comes $a b$ avo." Because criminal behaviour had such causes, punishment could not control it. ${ }^{94}$

Henry Maudsley was chiefly responsible for developing these themes in the 1870s. In 1873, after a conventional attack upon "moral" theories of insanity and a vindication of the indispensable nature of medical skills in the treatment of the mad, Maudsley proceeded to question whether any form of deviance could be understood on purely "moral" premises. The "wicked" he claimed, "are not wicked by deliberate choice ..., but by an inclination of their natures which makes the evil good to them and the good evil". In other words, lunacy and crime did not issue from the will of lunatics and criminals; their acts were the outcome of physical causes over which they had no conscious control. Maudsley concluded that "lunatics and criminals are as much manufactured articles as are steam-engines and calico-printing machines, only the processes of the organic manufactory are so complex that we are not able to follow them. They are neither accidents nor anomalies in the universe, but come by law and testify to causality; and it is the business of science to find out what the causes are and by what laws they work." 9

\footnotetext{
22 William A. F. Browne, 'Address: on medico-psychology', J. ment. Sci., 1866, 12: 309-327 (309-310).

${ }^{93}$ See Skultans, op. cit., note 29 above, pp. 246-258.

* J. B. Thomson, 'The hereditary nature of crime', J. ment. Sci., 1870, 15: 487-498 (488-491, 497-498).

9s Henry Maudsley, Responsibility in mental disease, London, Bradbury, Agnew, 1873, pp. 24, 28.
} 


\section{S. Jacyna}

Maudsley later went on to explain what these "laws" might be. The theory of evolution showed that organisms changed through time. The metaphysical "materialism" which he and others had adopted showed the full range of mental functions to depend upon the material organization; they too, therefore, were subject to development. However, there was no guarantee that evolution must be progressive: degeneration was as possible as improvement. Maudsley argued that insanity, crime, and other disorders associated with them were forms of human degeneracy brought about by modern social conditions; if these tendencies were allowed to continue "unchecked through generations, the natural termination would be sterile idiocy and extinction of the family." This could only be averted by a rational social policy:

If man will but make himself the subject of serious scientific study, he shall find that this working out of degeneracy through generations affords him a rational explanation of most of those evil impulses of the heart which he has been content to attribute to the devil .... Man's future progress or degeneracy depends on his comprehending the laws of evolution by scientific methods. This is the true basis of morality - not religion.\%

Maudsley elsewhere developed the disease metaphor of social deviance to suggest an attitude and a policy towards "degenerates". They should be regarded as a "morbid variety" in the social organism, which hindered its evolution. All those who fell into this widely-defined category were, ipso facto, "anti-social elements".97

The analogy could be extended to include the proper therapy for these social diseases. Maudsley held that the

comparison of the social fabric with the bodily organism is well founded and instructive. As in bodily disease there is a retrograde metamorphosis of formative action whereby morbid elements are produced which cannot minister to healthy function, but will, if not got rid of, occasion disorder or death; so in the social fabric there is likewise a retrograde metamorphosis whereby morbid varieties or degenerates of the human kind are produced, which, being antisocial, will, if not rendered innocuous by sequestration in it, or if not extruded violently from it, give rise to disorder incompatible with its stability. ${ }^{98}$

Maudsley did not detail the means of "sequestration" and "violent extrusion". However, he held that persons liable, because of their hereditary make-up, to produce insane or criminal children were "unfitted to breed together". ${ }^{99}$ Society, for its protection, should presumably discourage such unions.

With hindsight, it is possible to detect an affinity between these utterances and the later rhetoric of the eugenics movement in Britain. In both cases there is the stress upon the character of society being the sum of the characters of individuals; on the physical foundations of those traits; and on the need to intervene in the processes of reproduction if society is to avoid decay and disintegration. The similarity between the two genres is emphasized by the fact that Maudsley cited the researches of two of the pioneers of eugenic thought, Francis Galton and George Darwin. ${ }^{100}$

Moreover, there was a comparable political tendency to these forms of rhetoric. As

\footnotetext{
* Henry Maudsley, 'Materialism and its lessons', Fortnightly Rev., 1879, 26: 244-260 (255-257).

${ }^{97}$ Henry Maudsley, The pathology of mind, London, Macmillan, 1879, p. 105.

Ibid., p. 115.

9 Ibid., pp. 95-96.

100 Ibid., 118-120. On Galton and the origins of eugenic thought in Britain see Ruth S. Cowan, 'Nature and nurture: the interplay of biology and politics in the work of Francis Galton', Stud. Hist. Biol., 1977, 1: 133-208.
} 


\section{Somatic theories of mind and the interests of medicine}

Roger Smith has pointed out, Maudsley's concept of the madman as an "organic machine automatically impelled by disordered nerve-centres" was more than a metaphor: "it was also a programme for social action". This programme denied the rationality and utility of a punitive attitude to the insane and those suffering from related diseases, and recommended instead a policy of management, treatment, and prevention. Certain professional skills would be at a premium in the implementation of such measures; Maudsley called for a society "in which doctors acted as technological experts, isolating and caring for degenerate elements." 101

Maudsley's development of psychiatric physicalism can therefore be seen as an early expression of the political ambitions that later eugenists were to pursue. If implemented, the eugenic policy would have raised the "new professionals" - and especially the medical profession - to new heights of social importance. To them would fall the tasks of researching, formulating, and implementing the policies needed to improve the racial stock. In short, eugenics became a peculiarly pure expression of the aspirations of the medical profession as the nineteenth century drew to a close. ${ }^{102}$ However, much the same ambitions, and something of the same assumptions and modes of reasoning, had been manifested in previous attempts to find "scientific" solutions to social issues.

It is possible, therefore, to discern a convergence of several cultural flows in later Victorian Britain. A variety of resources were being utilized to produce a naturalistic account of man and society with certain practical implications which were held to follow from this naturalism. The hereditarianism of Francis Galton was one form this endeavour took; the physicalist theories of mind propounded by Maudsley another. Both tended to indicate certain courses which society must follow if it were to escape disaster: courses which would necessitate the transfer of resources and authority to those possessing the scientific knowledge needed to deal with the pressing problems of racial degeneracy.

From this perspective, the strategy of the alienists in their struggles for professional autonomy and expansion appears as a local manifestation of a more general social event. Moreover, the form of their strategy, with its attempt to bind the mental and the physical together was typical of the naturalism that accompanied the efforts of the new professionals to gain status elsewhere. At the same time, the specialized doctrines of the dependence of mind upon bodily organization expounded by the alienists provided an underpinning for the wider physicalism invoked by those intent on extending the "pathological" model of deviance.

This account has suggested that, at both the more special and at the general level, an understanding of such naturalism cannot rest upon the ideas involved in themselves. These need to be examined in the context in which they were articulated if their full meaning is to emerge. This context comprised the material relations of the medical profession in Victorian Britain, and it is through an investigation of these

${ }^{101}$ Smith, op. cit., note 73 above, pp. 52, 56.

102 See Donald A. MacKenzie, 'Eugenics in Britain', Soc. Stud. Sci., 1976, 6: 499-532; idem, Statistics in Britain, 1865-1930; the social construction of scientific knowledge, Edinburgh University Press, 1981, chap. 2. 


\section{S. Jacyna}

relations that an understanding of other aspects of medical science during this period may emerge.

\section{SUMMARY}

This paper is concerned with the content of British mental pathology in the midnineteenth century and with the uses to which these ideas were put. The 1840s saw major changes in neuroscience, brought about especially by the general acceptance of reflex action as the mode of operation of most, if not all, nervous centres, and by the application of microscopic analysis and cell theory to the elucidation of the intimate structure of the nervous system. British medical psychologists stressed the importance of these developments to an understanding of insanity. However, their emphasis upon the novelty of their views obscured a considerable continuity with earlier physicalist aetiologies of madness. In particular, inflammation - conceived as in essence a circulatory disorder - remained central to the theories of the somatic bases of mental disorder that were advanced. Although psychiatric writers maintained that such conceptions of the causes of madness were the only foundation for rational therapeutics, there was little connexion between their espoused pathological views and their clinical practice. The principal use of such notions was polemical: physicalism was deployed in the alienists' efforts to entrench and to enhance their professional prerogatives. In this regard, also, there was much continuity between the mid-Victorian period and the early decades of the nineteenth century.

\section{ACKNOWLEDGEMENTS}

I would like to to thank Bill Bynum, Roy Porter, and the anonymous referees of Medical History for their comments on an earlier version of this paper. I am also grateful to Charlotte Mackenzie for giving me access to the biographical information on British alienists she has collected. 